\title{
Some species of Tropocyclops (Crustacea, Copepoda) from Brazil, with a key to the American species
}

\author{
Janet W. Reid \\ Department of Invertebrate Zoology, NHB-163, National Museum of Natural History, Washington, DC \\ 20560, U.S.A.
}

Keywords: Taxonomy, Copepoda, Cyclopoida, Tropocyclops, new species, Brazil

\begin{abstract}
Collections from the Brazilian Planalto and Amazon regions contained several species of the cyclopoid copepod genus Tropocyclops. The morphology of $T$. schubarti is discussed; new records of this species extend its known distribution westward to the Brazilian Amazon and central highlands. Morphological characteristics of some populations of the $T$. prasinusgroup are most similar to $T$. prasinus mexicanus and $T$. prasinus s. str. Tropocyclops federensis $\mathrm{n}$. $\mathrm{sp}$. and $T$. nananae $\mathrm{n}$. sp. are described from the Distrito Federal. A key and chart are provided for the identification of species of Tropocyclops recorded from the Americas.
\end{abstract}

\section{Résumé}

Des échantillons prélevés dans les régions du Planalto brésilien et de l'Amazonie contiennent plusieurs espèces du genre de Copépodes Cyclopoïdes Tropocyclops. On discute la morphologie de $T$. schubarti; de nouvelles captures de cette espèce permettent d'étendre du côté ouest son aréal connu en Amazonie du Brésil et dans les hauts plateaux du centre du pays. Par leurs particularités morphologiques certaines populations du groupe de $T$. prasinus se rapprochent beaucoup de $T$. prasinus mexicanus et de $T$. prasinus s. str. On décrit $T$. federensis $\mathrm{n}$. sp. et $T$. nananae n. sp. du Distrito Federal. On donne une clé et un tableau pour la détermination des espèces de Tropocyclops connues des Amériques.

\section{Introduction}

In a collection of cyclopoid copepods from Brazilian Amazonia which was sent to me for identification by Mestre Bárbara Robertson, and in my personal collections from wetlands and ponds in Amazonia and the central Brazilian highlands (Planalto), there occurred several species of Tropocyclops. Many populations accorded well with $T$. prasinus meridionalis (Kiefer, 1931), the common planktonic South American subspecies (Reid, 1985), and those records are not listed here. Much material was referable to $T$. schubarti (Kiefer, 1935), although morphological characteristics of some populations differ from previous reports. The morphology of some populations, members of the $T$. prasinus-complex, does not fit with $T . p$. meridonalis, and is discussed. The new species $T$. federensis and $T$. nananae are described from several bodies of water in the Distrito Federal. A key and chart are provided for identification of the American species of the genus.

\section{Taxonomic section}

Tropocyclops schubarti (Kiefer, 1935)

(Figs. 1-4; Table I)

Material. - Col. E.N.S. Silva, 8 ९ १, $5 \sigma^{\circ} \propto, 4$ copepodids, undissected, and 1 \%, dissected on slide, all from Balbina Lago I, State of Amazonas (AM), $02^{\circ} 00^{\prime} \mathrm{S} 60^{\circ} 20^{\prime} \mathrm{W}, 24 \mathrm{Feb} .1986$, United States National Museum (USNM) 242450. Sample 94, 39 ㅇ ९, $16 \sigma^{\circ} \sigma^{\circ}$, small puddle in leaf litter on forest floor in Mato Grosso about $135 \mathrm{~km} \mathrm{N.E.} \mathrm{of} \mathrm{Vilhena,} \mathrm{Rondônia,} \mathrm{about} 11^{\circ} \mathrm{S}$ $59^{\circ} \mathrm{W}$, Museu de Zoologia da Universidade de São Paulo (MZUSP) 9717; 2 ९ \%, 5 ○ $0^{\circ}, 3$ copepodids, sample 96, backwater of unnamed river near site of sample 94, USNM 242221; 10 ९, $4 \circ \sigma^{\circ}, 9$ copepodids, sample 98 , backwater of tiny 
Table I. Measurements of females of Tropocyclops schubarti from Brazil (units in $\mu \mathrm{m} ; \mathrm{L}=$ length, $\mathrm{W}=$ width; $\mathrm{i}=\mathrm{inner}, \mathrm{o}=$ outer).

\begin{tabular}{|c|c|c|c|c|c|c|}
\hline \multirow{2}{*}{$\begin{array}{l}\text { Body } \\
\text { length }\end{array}$} & \multirow{2}{*}{$\frac{\text { Caudal ramus }}{L: W / \text { ratio } L: W}$} & \multicolumn{2}{|c|}{ Caudal ramus, setae } & \multicolumn{3}{|c|}{ Leg 4 endopodite 3} \\
\hline & & dorsal & i-o terminal & L:W/ratio L:W & i:o terminal spine & i spine: $L$ article \\
\hline \multicolumn{7}{|c|}{ Balbina Lago I, Amazonas } \\
\hline 720 & $45: 20 / 2.25: 1$ & 65 & $60: 305: 235: 56$ & $42: 16 / 2.6: 1$ & $84: 42$ & $2.0: 1$ \\
\hline 700 & $37: 19 / 1.95: 1$ & 63 & $66: 260: 180: 50$ & $40: 14 / 2.8: 1$ & $82: 42$ & $2.0: 1$ \\
\hline 750 & $42: 19 / 2.21: 1$ & 70 & $67: 356: 220: 48$ & $41: 16 / 2.6: 1$ & $82: 37$ & $2.0: 1$ \\
\hline \multicolumn{7}{|c|}{ Mato Grosso } \\
\hline 712 & $32: 19 / 1.7: 1$ & 61 & $64: 348: 208: 46$ & $35: 15 / 2.3: 1$ & $66: 32$ & $1.9: 1$ \\
\hline 564 & $33: 15 / 2.2: 1$ & 50 & $45: 260: 144: 36$ & $28: 12 / 2.3: 1$ & $57: 25$ & $2.0: 1$ \\
\hline 592 & $38: 16 / 2.4: 1$ & 45 & $42: 272: 136: 36$ & $28: 13 / 2.1: 1$ & $60: 23$ & $2.1: 1$ \\
\hline \multicolumn{7}{|c|}{ Distrito Federal } \\
\hline 660 & $43: 18 / 2.4: 1$ & 38 & $42: 192: 120: 29$ & $34: 13 / 2.6: 1$ & $65: 22$ & $1.9: 1$ \\
\hline 516 & $33: 16 / 2.0: 1$ & 27 & $36: 256: 128: 23$ & $32: 12 / 2.6: 1$ & $58: 28$ & $1.8: 1$ \\
\hline 552 & $32: 18 / 1.8: 1$ & 32 & $32: 264: 128: 22$ & $33: 13 / 2.5: 1$ & $62: 28$ & $1.9: 1$ \\
\hline
\end{tabular}

brook running over leaf litter near site of sample 94, USNM 242222; 1 \%, sample 99, small pool on tiny trickle leading into river near site of sample 94, USNM 242223; 5 ᄋ $\%, 4 \sigma^{\circ} \%, 3$ copepodids, sample 100 , woodland puddle near site of sample 94, USNM 242224; all col. June 1980 by A.E. Mill. Sample 107, $10^{\circ}$, pool in riverbed at confluence of Córregos Conceição and Brejo, Goiás (GO), $15^{\circ} 21^{\prime} 30^{\prime \prime} \mathrm{S} 47^{\circ} 23^{\prime} 07^{\prime \prime} \mathrm{W}, 13$ July 1980 , USNM 242225; 1 \%, $10^{\circ}, 1$ copepodid, sample 108, Rio Capim Puba, GO, $15^{\circ} 25^{\prime} 53^{\prime \prime} \mathrm{S} 47^{\circ} 22^{\prime} 26^{\prime \prime} \mathrm{W}, 13$ May 1980, USNM 242226; 7 ९ , 2 ơ ơ, sample 122, marsh, Estação Florestal Cabeça do Veado, Distrito Federal (DF), 27 Aug. 1980, col. I.G. Torres-Pereira, USNM 242227; 8 \&,, $3 \sigma^{\circ} \sigma$, sample 122, MZUSP 9718; 1 \& , 1 copepodid, sample 138, Córrego Rajadinha, DF, $15^{\circ} 44^{\prime} 15^{\prime \prime} \mathrm{S} 47^{\circ} 39^{\prime} 40^{\prime \prime} \mathrm{W}, 25$ May 1981, USNM 242228; $2 \sigma^{\circ} \circ, 5$ copepodids, sample 151, Rio Ituxi, near hamlet of Floresta, AM, 2 July 1981, col. A.B. Bosworth, USNM 242229; $1 \sigma^{\circ}$, dissected on slide, sample 140, Lago Paranoá, DF, 19 June 1981, USNM 242230. Numbered samples are from the author's collection, and were taken by the author unless otherwise noted. Unnumbered samples were sent by B. Robertson. Unmounted specimens are preserved in $70 \%$ ethanol.

Female. - Specimens from the Amazon and the central highlands (Figs. 1-4, Table I) agree in general with the diagnosis of Tropocyclops schubarti as originally described from Pernambuco by Kiefer (1935), and subsequently elaborated by Herbst (1959) from two specimens from São Paulo, particularly in the general proportions of leg 4 endopodite 3 and its terminal spines. Peculiar charac- teristics of $T$. schubarti shared by all these individuals are the insertion of the dorsal caudal seta at the same level or only slightly posterior to the level of insertion of the lateral seta, and the two groups of very long hairs on the margin of the coupler of leg 4. The present specimens have in addition a single row of small hairs on the posterior surface of the leg 4 coupler.

Most of the females differ from Kiefer's and Herbst's descriptions in having more slender caudal rami, although the caudal rami of some females from Mato Grosso are only 1.7 times longer than broad (Table I), as stout as those from São Paulo described by Herbst. The innermost terminal caudal setae in most specimens are not markedly longer than the outermost, although Kiefer noted that the ratio was about $2: 1$. In only one population, specimens from sample 122, are the outer terminal spines of the leg 4 endopodite 3 crossed over the inner, a feature noted by both Kiefer and Herbst.

Morphological characters not mentioned by Kiefer and Herbst otherwise coincide with Gurney's (1933) description of $T$. prasinus s. str. (Fischer, 1860), except in a few respects. Antenna articles 1 and 2 are distinct. The leg 1 coupler is without ornament. The couplers of legs 2 and 3 are ornamented similarly to that of leg 4 , except the marginal hairs are somewhat shorter. 


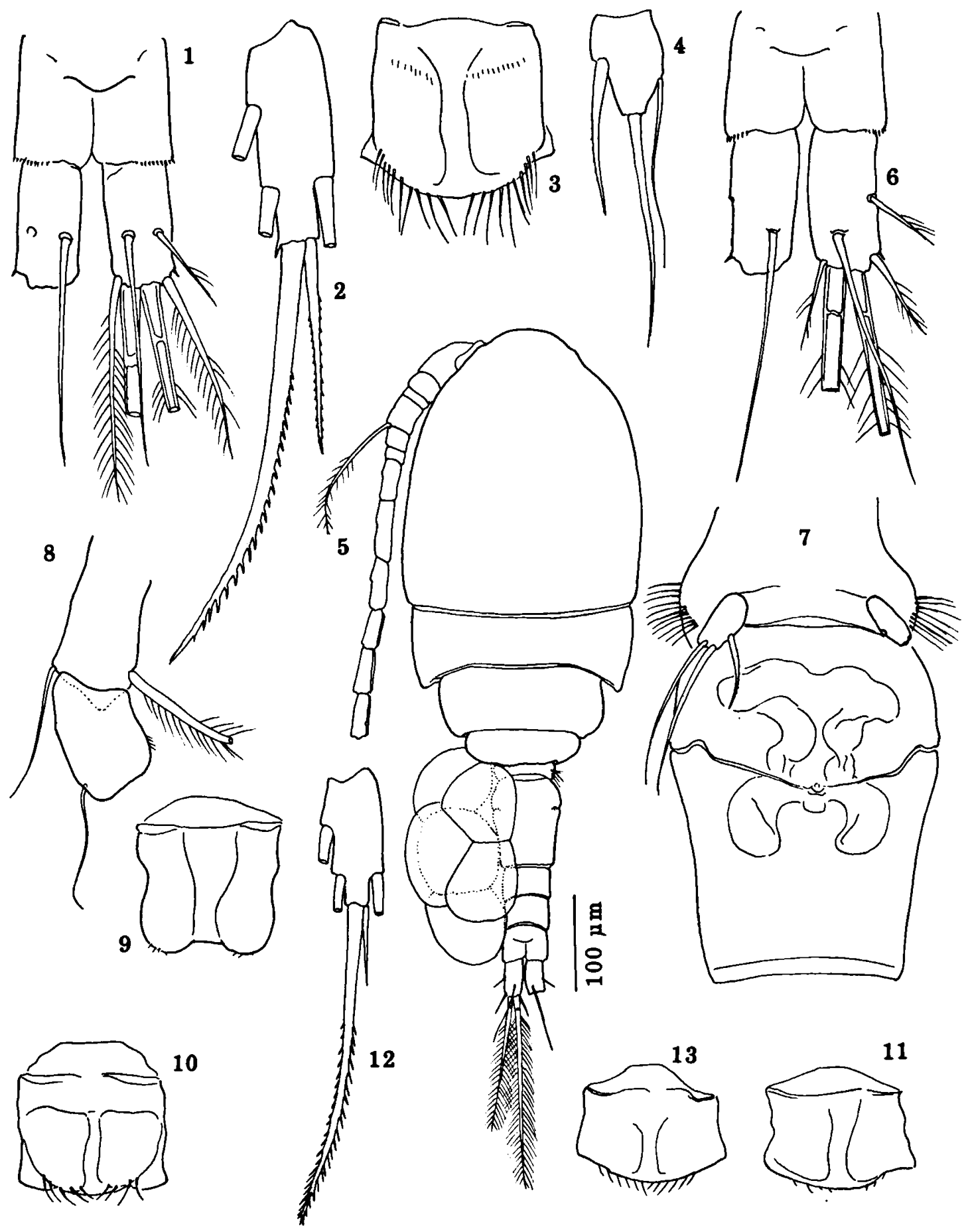

Figs. 1-4. Tropocyclops schubarti (Kiefer, 1935), \& from Balbina, Amazonas: 1, caudal rami, dorsal; 2, leg 4 endopodite 3; 3, leg 4 coupler; 4 , leg 5.

Figs. 5-12. Tropocyclops prasinus (Fischer, 1860), s. lat., ९ from Balbina, Amazonas: 5, habitus, dorsal; 6, caudal rami, dorsal; 7 , genital segment and leg 5, ventral; 8, antenna articles 1-2; 9, leg 1 coupler; 10, leg 3 coupler; 11, leg 4 coupler; 12, leg 4 endopodite 3. Fig. 13. Tropocyclops prasinus s. lat., $\&$ from sample 137, Distrito Federal, leg 4 coupler. (Scale refers to Fig. 5 only; remaining figures not to same scale.) 
Male. - Lengths $0.48-0.50 \mathrm{~mm}$. Similar to description of Kiefer (1935).

Color of formalin-preserved specimens of both sexes light brown.

Discussion. - Kiefer (1935) based his diagnosis of $T$. schubarti on a comparison to $T$. prasinus meridionalis Kiefer, 1931, another South American species with similar spine formula $(3,4,4,3)$ and stout caudal rami. $T$. schubarti was distinguished by stouter caudal rami (the rami of Kiefer's specimens measured 1.5 times longer than broad) and a long innermost terminal caudal seta, that is almost twice as long as the outermost terminal seta. Kiefer further remarked upon the unusual anterior insertion of the dorsal caudal seta and illustrated, but did not emphasize, the long hairs on the leg 4 coupler.

Measurements of specimens from various populations here attributed to $T$. schubarti, because of the position of the insertion of the dorsal caudal seta and the ornamentation of the leg 4 coupler, reveal a good deal of variation, even between adjacent populations such as those from Mato Grosso (Table I). The length/width ratios of the caudal rami of many of these specimens fall within or exceed the range for $T$. prasinus meridionalis (cf. Table V). Other ratios such as those of the length/ width ratio of leg 4 endopodite 3 , the length of the inner terminal spine of this article to the length of the article, and of the length of the dorsal caudal seta to the length of the caudal ramus, in a few specimens approach the limits of variation of $T$. prasinus meridionalis. The utility of these ratios is diminished correspondingly. The most useful recognition characters for $T$. schubarti, then, seem to be the level of insertion of the dorsal caudal seta and the long hairs on the leg 4 coupler.

Kiefer's specimens were collected from bromeliads in a small forest near Recife, Pernambuco, and Herbst's from bromeliads in the state of São Paulo. These new records from small ponds and rivulets extend the range of known habitats of this relatively robust species. The known geographical distribution in Brazil is also considerably extended, to the central and southwestern Amazon and upper Paraná River basins.
Tropocyclops prasinus (Fischer, 1860) s. lat.

a. Populations from Balbina, Amazonas

(Figs. 5-12; Table II)

Material. - More than $200 \%$,$\sigma^{\circ} \sigma$, copepodids, undissected, and $2 \odot \odot$, each dissected on slide, Balbina Lago I, 24 Feb. 1986, USNM 242451; 16 १ , 8 o $\sigma^{*}, 34$ copepodids, undissected, and 1 \&, dissected on slide, Balbina Lago I, 8 Mar. 1986, USNM 242452; 5 ९ ९ , 5 ○ $\circ, 20$ copepodids, undissected, Balbina Lago II, 24 Feb. 1986, USNM 242455; more than 50 ९ ᄋ, $\sigma^{\circ} \sigma^{\circ}$, copepodids, undissected, and $1 \sigma^{\circ}$, dissected on slide, Balbina Lago II, 3 Mar. 1986, USNM 242453; 5 \& ९, 5 o $\sigma^{\circ}, 10$ copepodids, Balbina Lago II, 9 Mar. 1986, USNM 242454. Col. E.N.S. Silva.

Female. - In these specimens (Figs. 5-12; Table II), the proportions of the caudal rami (about 2.5 times longer than broad) and the ratio of the lengths of the dorsal seta and innermost terminal caudal seta $(1.75-3: 1)$ correspond better to the diagnosis of $T$. prasinus mexicanus Kiefer, 1938, as redescribed by Lindberg (1955b) than to the widely distributed South American subspecies $T$. prasinus meridionalis (Table V). The proportions of the leg 4 endopodite 3 are intermediate between those of these subspecies. Regarding characters which have not been described for either subspecies, the Balbina specimens are similar to the description of $T$. prasinus s. str. by Gurney (1933), except that article 1 of the antenna is distinct from article 2 and bears only 2 setae (Fig. 8); other differences lie in the ornamentation of the couplers of legs $1-4$, the coupler of leg 1 having tiny hairs on the margin, those of legs 2-3 with longer hairs, and that of leg 4 with very few short hairs, no hairs being visible on the surface of the coupler of any leg (Figs. 9-11).

Male. - Similar to Kiefer's (1938) description of $T$. prasinus mexicanus.

Color of formalin-preserved specimens of both sexes dark purple.

Discussion. - Since the variation, and hence the utility in species discrimination, of the setation of the antenna and the ornamentation of the couplers of the swimming legs is unknown for most species and subspecies of Tropocyclops, little can be said at 
Table II. Measurements of females of Tropocyclops prasinus s. lat. from Brazil (units and abbreviations as in Table I).

\begin{tabular}{|c|c|c|c|c|c|c|}
\hline \multirow{2}{*}{$\begin{array}{l}\text { Body } \\
\text { length }\end{array}$} & \multirow{2}{*}{$\frac{\text { Caudal ramus }}{\mathrm{L}: \mathrm{W} / \text { ratio } \mathrm{L}: \mathrm{W}}$} & \multicolumn{2}{|c|}{ Caudal ramus, setae } & \multicolumn{3}{|c|}{ Leg 4 endopodite 3} \\
\hline & & dorsal & $\mathrm{i}-\mathrm{o}$ terminal & L:W/ratio L:W & i:o terminal spine & i spine: $L$ article \\
\hline \multicolumn{7}{|c|}{ a. Lagos I and II, Balbina, Amazonas } \\
\hline (I) 500 & $27: 11 / 2.5: 1$ & 35 & $20: 140: 105: 20$ & $26: 11 / 2.4: 1$ & $62: 14$ & 2.4:1 \\
\hline (I) 520 & $30: 12 / 2.5: 1$ & 40 & $18: 140: 100: 20$ & $28: 12 / 2.3: 1$ & $65: 16$ & 2.3:1 \\
\hline (I) 500 & $28: 11 / 2.5: 1$ & 45 & $15: 150: 105: 22$ & $26: 11 / 2.4: 1$ & $60: 15$ & $2.3: 1$ \\
\hline (II) 490 & $30: 12 / 2.5: 1$ & 40 & $16: 150: 105: 16$ & $28: 12 / 2.3: 1$ & $65: 15$ & 2.3:1 \\
\hline \multicolumn{7}{|c|}{ b. Pool near Córrego Rajadinha, Distrito Federal (Sample 137) } \\
\hline 620 & $45: 16 / 2.8: 1$ & 62 & $40: 256: 152: 32$ & $37: 13 / 2.8: 1$ & $70: 28$ & $1.9: 1$ \\
\hline 604 & $43: 17 / 2.5: 1$ & 52 & $36: 264: 148: 34$ & $35: 13 / 2.7: 1$ & $73: 26$ & 2.1:1 \\
\hline 592 & $41: 16 / 2.5: 1$ & 50 & $40: 260: 144: 32$ & $32: 13 / 2.5: 1$ & $65: 26$ & 2.0:1 \\
\hline \multicolumn{7}{|c|}{ c. Well near Córrego Capão da Onça, Distrito Federal (Sample 139) } \\
\hline 600 & $28: 16 / 1.75: 1$ & 55 & $38: 188: 152: 33$ & $31: 12 / 2.6: 1$ & $64: 25$ & 2.1:1 \\
\hline 564 & $33: 15 / 2.2: 1$ & 58 & $44: 188: 156: 31$ & $32: 12 / 2.7: 1$ & $65: 28$ & $2.0: 1$ \\
\hline 540 & $32: 15 / 2.1: 1$ & 55 & $42: 184: 152: 33$ & $30: 11 / 2.7: 1$ & $66: 25$ & $2.2: 1$ \\
\hline
\end{tabular}

present about the significance of these morphological features. Certainly the Balbina specimens agree in some respects with the present diagnosis of $T$. prasinus mexicanus, which has been recorded from most of North and Central America and from several of the Antilles, although never from continental South America.

The proportions of the caudal rami and of leg 4 endopodite 3 , as well as the relative lengths of the caudal setae and the terminal spines of leg 4 endopodite 3 have been given great weight by many authors in defining species and subspecies within the genus Tropocyclops, particularly the $T$. prasinus-complex (Table V). However, a critical evaluation of the limits of variation within and between populations belonging to this species-complex has not yet been accomplished. The ornamentation of the leg 4 coupler may also be useful, although this character is not always included in descriptions. There is apparently some variation in the nature of the coupler ornamentation between populations ascribed to $T$. prasinus s. str. (Table V). Gurney (1933) showed the leg 4 coupler of the British form of $T$. prasinus s. str. with short marginal hairs. Dussart (1983), describing a female from Guadeloupe which he attributed to $T$. prasinus s. str., figured long hairs on the coupler. Until a revision of the genus becomes possible, it seems best to refer the Bal- bina specimens to $T$. prasinus $\mathrm{cf}$. mexicanus.

b. Population from sample 137, Distrito Federal (Fig. 13; Table II)

Material. - Sample 137, 30 ९ , $\sigma^{\circ}$, undissected, and 1 , dissected on slide, from pool near Córrego Rajadinho, DF, $15^{\circ} 44^{\prime} 15^{\prime \prime S} 47^{\circ} 39^{\prime} 40^{\prime \prime} \mathrm{W}, 25$ May 1981, USNM 242207.

Female. - Measurements of females from this sample correpond closely to those of European specimens of $T$. prasinus s. str. (cf. Table V). The hairs on the margin of the leg 4 coupler (Fig. 13) are relatively longer than those figured by Gurney (1933). Color of formalin-preserved specimens light tan.

c. Population from sample 139, Distrito Federal (Table II)

Material. - Sample 139, 5 ९ , $2 \sigma^{\circ} \circ$, shallow dug well near Córrego Capāo da Onça, DF, about $15^{\circ} 49^{\prime} \mathrm{S} 47^{\circ} 39^{\prime} \mathrm{W}, 25$ May 1981, USNM 242206.

Female. - The proportions of the caudal rami and of the length of the leg 4 inner terminal spine to the length of the endopodite 3 of these specimens places them closer to the diagnosis of $T$. prasinus s. str. than to $T$. prasinus meridionalis (Table II). Color 
Table III. Tropocyclops federensis n. sp., Distrito Federal (units and abbreviations as in Table I).

\begin{tabular}{|c|c|c|c|c|c|c|}
\hline \multirow{2}{*}{$\begin{array}{l}\text { Body } \\
\text { length }\end{array}$} & \multirow{2}{*}{$\frac{\text { Caudal ramus }}{\mathrm{L}: \mathrm{W} / \text { ratio } \mathrm{L}: \mathrm{W}}$} & \multicolumn{2}{|c|}{ Caudal ramus, setae } & \multicolumn{3}{|c|}{ Leg 4 endopodite 3} \\
\hline & & dorsal & $\mathrm{i}-\mathrm{o}$ terminal & $\mathbf{L}: \mathrm{W} /$ ratio $\mathrm{L}: \mathrm{W}$ & i:o terminal spine & i spine: $L$ article \\
\hline 550 & $39: 16 / 2.4: 1$ & 59 & $27: 212: 172: 29$ & $29: 11 / 2.6: 1$ & $66: 18$ & 2.3:1 \\
\hline 590 & $43: 18 / 2.4: 1$ & 75 & $24: 220: 168: 28$ & $29: 13 / 2.2: 1$ & $68: 22$ & 2.3:1 \\
\hline 570 & $40: 15 / 2.7: 1$ & 60 & $21:-: 152: 25$ & $25: 12 / 2.1: 1$ & $63: 20$ & $2.5: 1$ \\
\hline 530 & $39: 15 / 2.6: 1$ & 50 & $27: 204: 168: 31$ & $24: 12 / 2.0: 1$ & $52: 17$ & $2.2: 1$ \\
\hline
\end{tabular}

of formalin-preserved specimens light tan.

Tropocyclops federensis $\mathrm{n}$. sp.

(Figs. 14-20; Table III)

Material. - Holotype $९$, MZUSP 9715; paratypes: $\odot$ (dissected on slide), MZUSP 9716; 2 \% $९$, 4 copepodids, USNM 242205; all from sample 10, Lagoa da Península Norte, Brasília, DF, $15^{\circ} 43^{\prime} 30^{\prime \prime} \mathrm{S} 47^{\circ} 51^{\prime} 30^{\prime \prime} \mathrm{W}, 18$ Sep. 1978.

Female. - Length of holotype $550 \mu \mathrm{m}$; of paratypes 530-590 $\mu \mathrm{m}$ (Table III). Body broadest at prosomite 2 in dorsal view (Fig. 14); genital segment slightly broadened anteriorly, genital field indistinct (Fig. 15). Caudal ramus (Fig. 16) 2.4-2.7 times longer than broad; lengths of caudal setae as in Table III.

Antennule when reflexed reaching slightly past posterior margin of prosomite 2. Antenna with only 2 setae on article 1 , similar to that of $T$. prasinus s. lat. from Balbina (Fig. 8). Mouthparts as described by Gurney (1933) for $T$. prasinus s. str.; maxillule, not figured by Gurney, without exceptional structure for family (Fig. 17).

Swimming legs $1-4$ (Figs. 18-20) with spine formula 3,3,3,3; leg 1 with seta on medial expansion of basipodite 2; legs 2 and 3 similar, with articles of exopodites and spines of exopodite articles 2 and 3 very broad. Couplers of legs 1 and 4 without ornament; couplers of legs 2 and 3 with two groups of hairs near margin. Leg 4 endopodite 3 2.0-2.6 times longer than broad; outer terminal spine of endopodite 3 short, less than one-third length of inner terminal spine (Table III).

Leg 5 (Fig. 15) with inner spine about equal in length to length of free article of leg; middle and outer setae very long, extending past posterior margin of genital segment.

Color of formalin-preserved specimens light tan.

Male. - Unknown.

Etymology. - Named for the type locality in the Distrito Federal.

Discussion. - Kiefer (1931) defined within the genus Tropocyclops a "Quaterni Group" of species with spine formula 3,4,4,3; and a "Terni Group" of species with spine formula $3,4,3,3$. All species previously described have one or another of these spine formulae except $T$. pseudoparvus Dussart \& Fernando, 1986, from Costa Rica, with spine formula $2,3,3,3$. $T$. federensis is therefore distinguished by a unique spine formula.

The other feature of this species which seems to be unusual is the broadened exopodites of legs 2 and 3, with their extremely stout outer spines. Figures of legs 2 and 3 of Tropocyclops species are rare in the literature. Gurney (1933) figured spines of these legs in $T$. prasinus as only slightly stouter than the spines of legs 1 and 4, and this is the case in all other species of Tropocyclops that I have seen. Dumont (1981: Fig. 8(3)) showed rather stout spines on the exopodite of leg 3 of $T$. levequei.

\section{Tropocyclops nananae $\mathrm{n} . \mathrm{sp}$.}

(Figs. 21-28; Table IV)

Material. - Holotype $९$, dissected on slide, sample 72, Lagoa da Peninsula Norte, DF, 29 June 1979, MZUSP 9712; paratypes: 3 ९ , $1 \sigma^{\circ}, 1$ copepodid, sample 136, pond near Ribeirão da Papuda, DF, about $15^{\circ} 54^{\prime} 0^{\prime \prime} \mathrm{S} 47^{\circ} 46^{\prime} 50^{\prime \prime} \mathrm{W}, 19$ May 1981, MZUSP 9713; 4 ९, $3 \circ^{\circ} \circ^{\circ}$, sample 214, marsh forming headwaters of Córrego do Acampamento near head- 


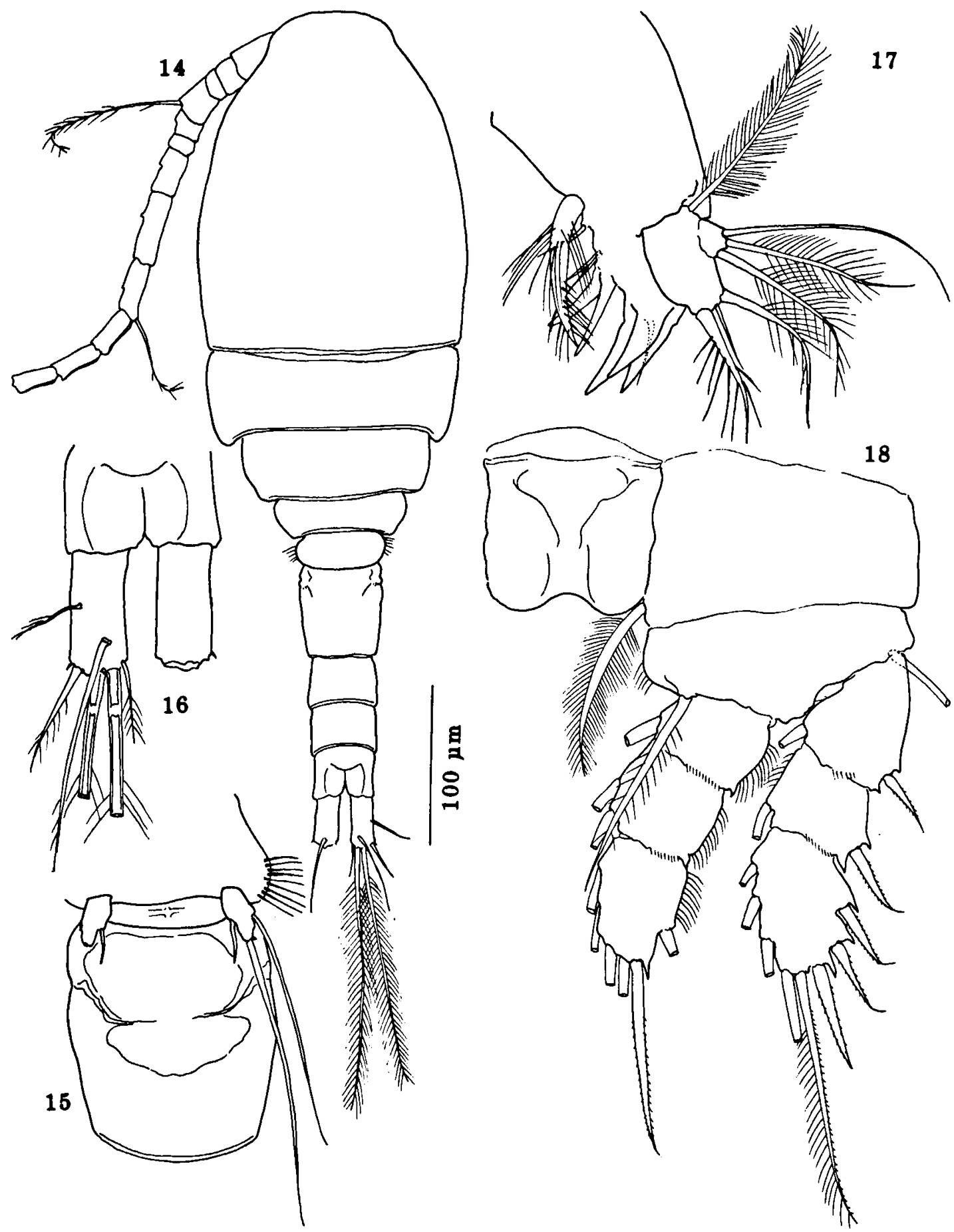

Figs. 14-18. Tropocyclops federensis n. sp., ९ : 14, habitus, dorsal; 15, genital segment and leg 5, ventral; 16, caudal rami, dorsal; 17, maxillule; 18, leg 1. (Scale refers to Fig. 14 only; remaining figures not to same scale.) 

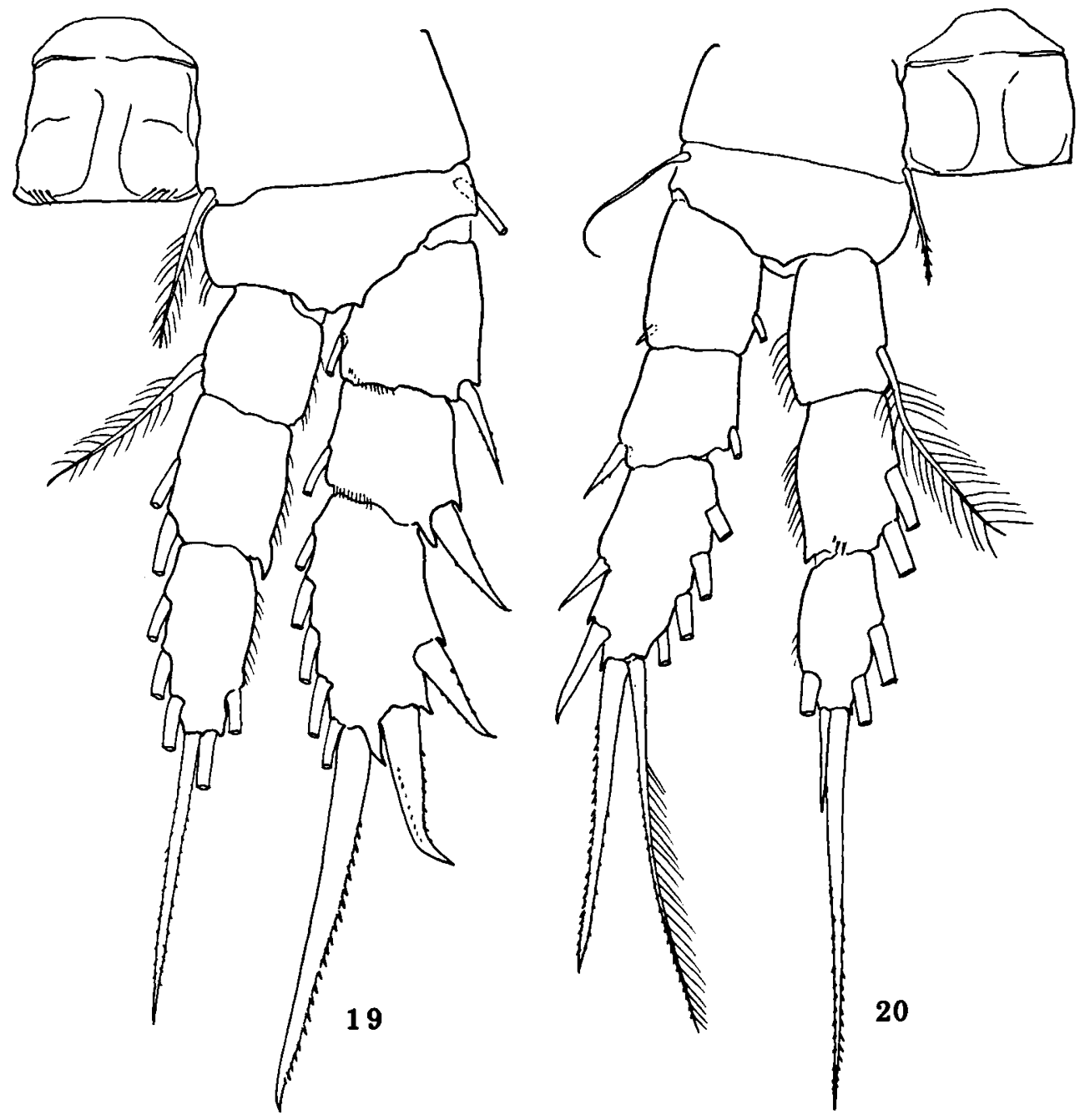

Figs. 19, 20. Tropocyclops federensis n. sp., ९: 19, leg 3; 20, leg 4.

quarters of Dragões da Independência, DF, $15^{\circ} 46^{\prime} 50^{\prime \prime} \mathrm{S}$ $47^{\circ} 58^{\prime} 07^{\prime \prime} \mathrm{W}, 8$ May 1982, MZUSP 9714; 3 ९ १, 1 copepodid, each on slide, sample 3, Lagoa da Península Norte, DF, 24 Aug. 1978, USNM 242201; 1 \%, on slide, 1 ९, 1 \%, 1 copepodid, sample 136, USNM 242202; 1 ९, marsh on north arm of Lago Paranoá, DF, 19 June 1981, USNM 242203; 3 \% \&, 3 \% \%, 1 copepodid, sample 214, USNM 242204.

Female. - Length of holotype $520 \mu \mathrm{m}$; of paratypes 420-540 $\mu \mathrm{m}$ (Table IV). Habitus (Fig. 21) much as $T$. federensis, except caudal ramus slender, in some specimens narrow at base and broadening distally (Fig. 22), in others stouter and more normally cylindrical (Fig. 23), 2.3-3.0 times longer than broad. Lengths of caudal setae as in Table IV. Genital seg- ment (Figs. 21, 24) slightly broadened anteriorly; seminal receptacle of all specimens indistinct.

Antennule reaching approximately to midlength of prosomite 3 . Antenna article 2 with only 2 setae. Mouthparts as in $T$. prasinus, figured by Gurney (1933).

Legs 1-4 (Figs. 25-27) with spine formula $3,4,3,3$; leg 1 with seta on inner expansion of basipodite 2; legs 2 and 3 with spines on exopodites 2 and 3 little enlarged. Distal margin of coupler of leg 4 slightly convex. Couplers of legs $1-3$ without ornament, coupler of leg 4 with short, sparse hairs on margin. Outer terminal spine of leg 4 endopodite article 3 , if present, closely appressed to inner ter- 


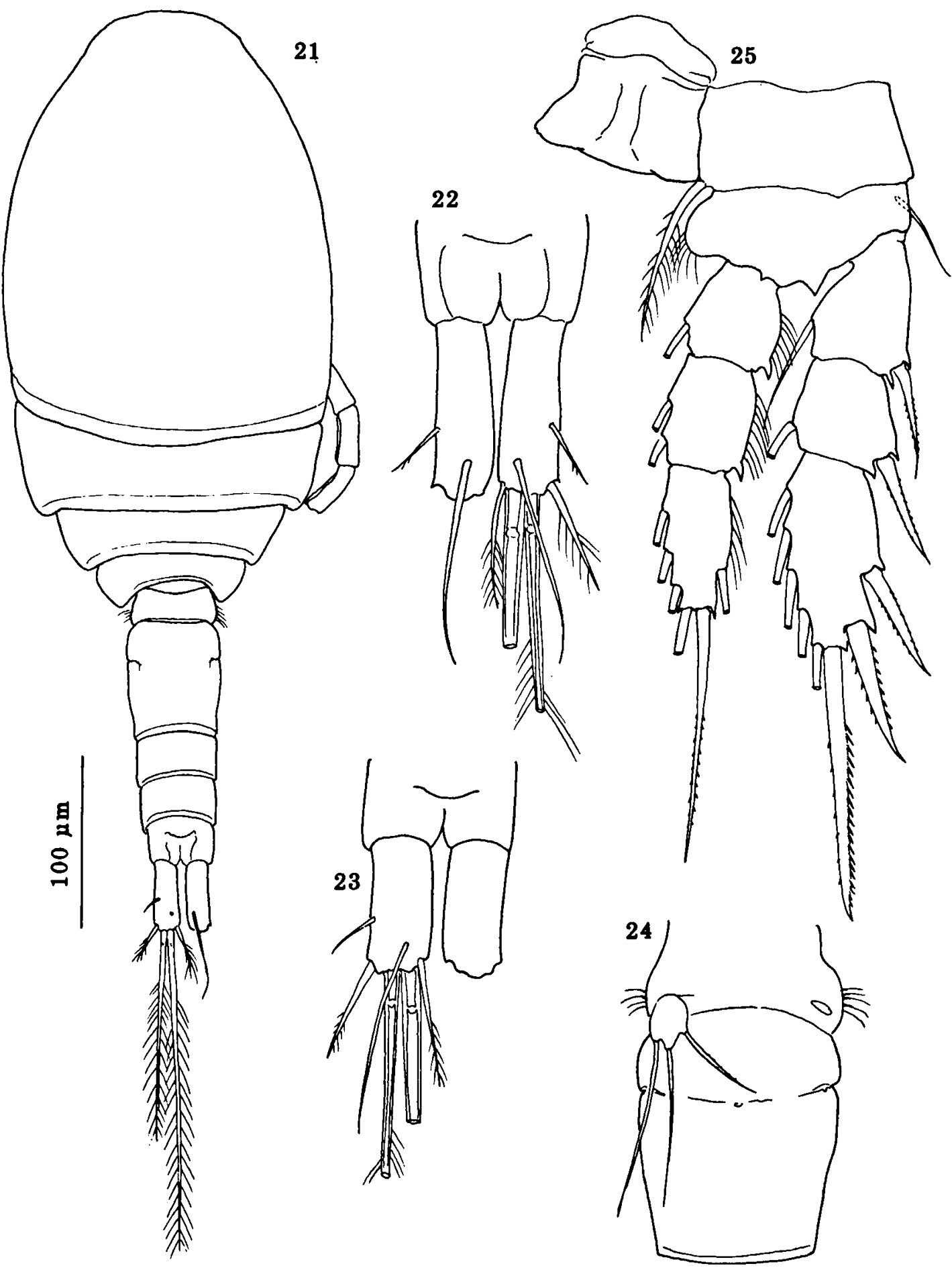

Figs. 21-25. Tropocyclops nananae n. sp., $९: 21$, habitus, dorsal; 22, caudal rami, dorsal; 23, caudal rami of another specimen, dorsal; 24 , genital segment and leg 5 , ventral; 25 , leg 3. (Scale refers to Fig. 21 only; remaining figures not to same scale.) 

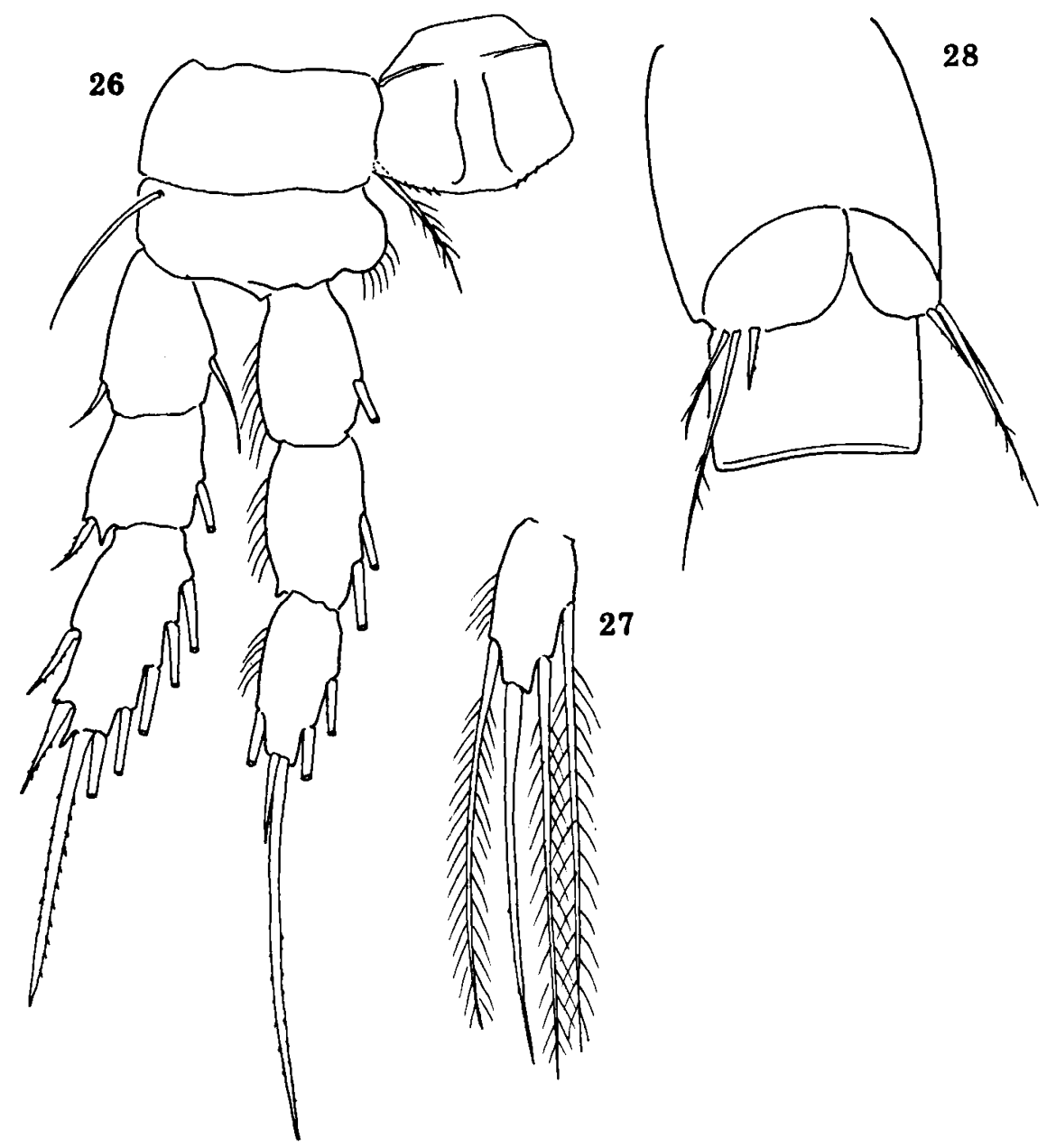

Figs. 26-28. Tropocyclops nananae n. sp. $(26,27, \diamond ; 28, \sigma): 26$, leg $4 ; 27$, leg 4 endopodite 3 of another specimen lacking outer terminal spine; 28 , leg 6.

minal spine and short, about half length of endopodite article 3 and $1 / 5$ length of inner terminal spine; several specimens lacking outer spine.

Leg 5 (Fig. 24) with inner spine longer than free article of leg, and middle and outer setae subequal in length, both setae shorter than length of genital segment.

Male. - Lengths 370-420 $\mu \mathrm{m}$. Morphology similar to description of Gurney (1933) for T. prasinus, except caudal ramus about 2.5 times longer than broad, in all specimens cylindrical, not narrowing at base; leg 6 (Fig. 28) with short inner spine and outer (dorsal) seta, middle seta reaching past posterior margin of succeeding somite.

Color of formalin-preserved specimens of both sexes light tan.

Etymology. - Named for the Yoruban and Brazilian Candomblé deity Nanan, oldest of the water nymphs.

Discussion. - The spine formula of $T$. nananae places this species in the Terni Group. Several species of this group differ from $T$. nananae in lacking a seta on the inner expansion of the basipodite of leg 1: T. tenellus (G.O. Sars, 1909), T. brevispinus Shen \& Tai, 1962, T. confinis (Kiefer, 1930) and its 
Table IV. Tropocyclops nananae n. sp., Distrito Federal (a, specimens from Brejo dos Dragões da Independência; b, Lago Paranoá; c, Lagoa da Península Norte; d, pond near Ribeirão da Papuda; some specimens lack an outer spine on leg 4 endopodite 3 ; units and abbreviations as in Table I).

\begin{tabular}{|c|c|c|c|c|c|c|}
\hline \multirow{2}{*}{$\begin{array}{l}\text { Body } \\
\text { length }\end{array}$} & \multirow{2}{*}{$\frac{\text { Caudal ramus }}{\mathrm{L}: \mathrm{W} / \text { ratio } \mathrm{L}: \mathrm{W}}$} & \multicolumn{2}{|c|}{ Caudal ramus, setae } & \multicolumn{3}{|c|}{ Leg 4 endopodite 3} \\
\hline & & dorsal & $\mathrm{i}-$ o terminal & L:W/ratio L:W & i:o terminal spine & i spine: $\mathrm{L}$ article \\
\hline a 520 & $38: 15 / 2.5: 1$ & 40 & $22: 180: 120: 21$ & $26: 11 / 2.4: 1$ & $49: 9$ & $1.9: 1$ \\
\hline a 520 & $39: 14 / 2.8: 1$ & 40 & $21: 188: 132: 26$ & $28: 12 / 2.3: 1$ & $55: 0$ & $2.0: 1$ \\
\hline a 480 & $41: 14 / 2.9: 1$ & 42 & $23: 188: 124: 22$ & $26: 10 / 2.6: 1$ & $57: 0$ & $2.2: 1$ \\
\hline b 520 & $32: 14 / 2.3: 1$ & 40 & $30: 188: 112: 27$ & $28: 10 / 2.8: 1$ & $46: 11$ & $1.6: 1$ \\
\hline c 540 & $40: 13 / 3.1: 1$ & 57 & $25: 192: 125: 30$ & $26: 13 / 2.0: 1$ & $60: 13$ & $2.3: 1$ \\
\hline c 540 & $42: 15 / 2.8: 1$ & 54 & $26: 180: 123: 28$ & $26: 12 / 2.2: 1$ & $62: 0$ & $2.4: 1$ \\
\hline c 420 & $33: 11 / 3.0: 1$ & 45 & $20: 172: 90: 21$ & $20: 10 / 2.0: 1$ & $50: 11$ & $2.5: 1$ \\
\hline d 552 & $33: 13 / 2.5: 1$ & 45 & $35: 200: 140: 22$ & $25: 12 / 2.1: 1$ & $58: 10$ & $2.3: 1$ \\
\hline d 530 & $33: 13 / 2.5: 1$ & 45 & $30: 156: 104: 25$ & $25: 12 / 2.1: 1$ & $48: 10$ & $1.9: 1$ \\
\hline d 568 & $33: 14 / 2.3: 1$ & 40 & $30: 184: 116: 26$ & $23: 11 / 2.1: 1$ & $57: 15$ & $2.5: 1$ \\
\hline
\end{tabular}

several subspecies, and T. polkianus Einsle, 1971; the latter two species were discussed by Dumont (1981). The descriptions of several other members of the Terni Group do not mention the presence or absence of this seta. Regarding these species, in $T$. confinis longifurca Dussart, 1982, the leg 4 endopodite 3 outer spine is about equal to the length of the endopodite 3 and slightly less than half the length of the inner spine. The caudal rami of $T$. parvus Kiefer, 1931, which is considered by some workers a synonym of $T$. tenellus (e.g. Dussart \& Fernando, 1986), and of $T$. brevis Dussart, 1972 are 2 times longer than broad, or shorter. $T$. rarus, described by Dussart (1984) from French Guiana, most resembles $T$. nananae in having caudal rami about 2.6 times longer than broad, and in having the leg 4 endopodite 32.6 times longer than broad. In $T$. rarus, the inner terminal spine of leg 4 endopodite 3 is 3.9 times the length of the outer terminal spine. The innermost terminal caudal seta of $T$. rarus is distinctly longer than the outermost terminal caudal seta, while the corresponding setae of $T$. nanan$a e$ are subequal in length. Dussart did not state whether $T$. rarus possesses a seta on the inner expansion of the basipodite of leg 1 . He described the leg 4 coupler of $T$. rarus as "bombée et relativement proéminente" (Dussart, 1984: 322), but mentioned no ornamentation. The male of $T$. nananae is distinguished from that of $T$. rarus by the long middle seta of leg 6 in the former species; the correspond- ing seta of $T$. rarus is subequal to the outer (dorsal) seta.

\section{Key to American species}

A key and table (Table V) to aid in the identification of species and subspecies of the genus Tropocyclops recorded from the Americas are presented below. The characters used in the key are mostly taken from the literature, principally after Kiefer $(1931,1956)$ and Lindberg (1955a, b, c).

Several diagnoses of species, subspecies, and forms of Tropocyclops are based on one or a few specimens from a single population, and some of these distinctions may well be found to be biologically invalid. For instance, Gurney (1933) questioned Kiefer's (1931) distinction between T. extensus s. str. and $T$. extensus f. longispina, each diagnosis based on material from a single population in New Jersey, U.S.A. Riera (1981) and Riera \& Estrada (1985) demonstrated that in the case of $T$. prasinus s. str. in Spain, morphometric relationships between body parts vary among populations from different reservoirs, in some cases from north to south in an apparent correlation with ambient temperature. Torke (1976), having consistently found morphs attributable to $T$. prasinus s. str. and $T$. prasinus mexicanus together in Wisconsin lakes, does not consider the latter to be a valid subspecies. 
Table $V$. Range of measurements and proportions reported for American subspecies of the Tropocyclops prasinus-complex (abbreviations as in Table I).

\begin{tabular}{|c|c|c|c|c|c|c|}
\hline \multirow[t]{2}{*}{ Subspecies } & \multirow{2}{*}{$\begin{array}{l}\text { Caudal ramus } \\
\text { ratio } L: W\end{array}$} & \multirow{2}{*}{$\begin{array}{l}\text { Dorsal seta: } \\
\text { caudal ramus }\end{array}$} & \multicolumn{4}{|c|}{ Leg 4 endopodite 3} \\
\hline & & & $\begin{array}{l}\text { ratio } \\
\text { L:W }\end{array}$ & $\begin{array}{l}\text { i:o apical } \\
\text { spine }\end{array}$ & $\begin{array}{l}\text { i spine : } \\
\text { L article }\end{array}$ & coupler \\
\hline prasinus s. str. (Fischer) & $2.0-2.6$ & $?$ & $2.3-2.6$ & $2.2-2.3$ & $1.5-2.0$ & short hairs \\
\hline p. jerseyensis (Kiefer) & $2.7-2.8$ & $?$ & 2.5 & 2.7 & 2.0 & $?$ \\
\hline p. meridionalis (Kiefer) & $1.7-2.0$ & $1.3-1.7$ & $2.5-2.7$ & $2.5-2.9$ & $2.2-3.1$ & short hairs \\
\hline p. mexicanus Kiefer & $2.1-2.5$ & $2.1-2.2$ & 2.1 & $2.7-2.9$ & 2.7 & short hairs \\
\hline p. aztequei Lindberg & $2.6-3.1$ & about 1 & $2.5-3.0$ & $1.8-2.1$ & 2.5 & $?$ \\
\hline p. peruviana Lindberga & $1.9-2.0$ & $1.5-1.9$ & $2.3-3.2$ & $2.8-3.5$ & 2.2 & fine hairs \\
\hline p. divergens Dussart & 3 (divergent) & $0.9^{\mathrm{b}}$ & 2.2 & 2.6 & 1.9 & naked \\
\hline
\end{tabular}

aSynonymized with $T$. prasinus meridionalis by Herbst (1959).

bMeasured from figure.

Probably because of similar doubts, Yeatman (1959) included only $T$. prasinus s. str. and $T$. prasinus mexicanus, and Pennak (1989) only $T$. prasinus s. str. in their keys to North American Cyclopoida. However, considering that failure to mention the existence of some named varieties leads to a general belief that questions regarding morphological variability within species-groups have been settled, when in fact such questions have hardly begun to be investigated, it seems useful to list these named varieties pending eventual revision of the genus.

\section{Key to females of the genus Tropocyclops in the Americas}

I. Spine formula $2,3,3,3 \ldots \ldots \ldots \ldots \ldots \ldots \ldots \ldots \ldots$ .......... T. pseudoparvus Dussart \& Fernando, 1986 (Costa Rica)

- Spine formula $3,3,3,3 \ldots \ldots \ldots \ldots \ldots$. . federensis $\mathrm{n} . \mathbf{s p}$. (Brazil)

- Spine formula $3,4,3,3 \ldots \ldots \ldots \ldots \ldots \ldots \ldots \ldots \ldots 2$

- Spine formula $3,4,4,3 \ldots \ldots \ldots \ldots \ldots \ldots \ldots \ldots 66$

2. Inner terminal spine of leg 4 endopodite $32.3-2.5$ times longer than outer terminal spine $\ldots \ldots \ldots \ldots \ldots \ldots, 3$

- Inner terminal spine of leg 4 endopodite 34-5 times longer than outer terminal spine $\ldots \ldots \ldots \ldots \ldots \ldots \ldots \ldots 4$

3. Caudal ramus about 2 times longer than broad ......... .................... T. confinis (Kiefer, 1930) (Eurasia, Africa; ? U.S.A.)

- Caudal ramus 2.3-2.4 times longer than broad .......... .............. T. confinis longifurca Dussart, 1983 (Guadeloupe)
4. Caudal ramus $2.5-3$ times longer than broad $\ldots \ldots \ldots$. 5

- Caudal ramus 2 times longer than broad .............. (Guatemala)

5. Outermost and innermost terminal caudal setae subequal in length; outer terminal spine of leg 4 endopodite 3 lacking or, if present, about $1 / 5$ length of inner terminal spine ...... $\ldots \ldots \ldots \ldots \ldots \ldots \ldots \ldots \ldots \ldots$ T nananae $\mathrm{n} . \mathrm{sp}$. (Brazil)

- Innermost terminal caudal seta 1.8 times length of outermost terminal caudal seta; outer terminal spine of leg 4 endopodite 3 about $1 / 4$ length of inner terminal spine ............ ....................... T. rarus Dussart, 1984 (French Guiana)

6. Caudal ramus 3.3-4.1 (usually about 4) times longer than

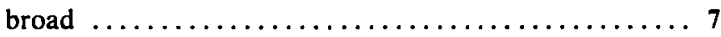

- Caudal ramus 3 times longer than broad, or shorter ... 8

7. Inner terminal spine of leg 4 endopodite $31.5-1.8$ times longer than endopodite $3 \ldots \ldots \ldots \ldots \ldots \ldots \ldots \ldots$ ...................... T. extensus (Kiefer, 1931) (U.S.A., New Jersey; ? Haiti)

- Inner terminal spine of leg 4 endopodite 3 2.2-2.5 times longer than endopodite $3 \ldots \ldots \ldots \ldots \ldots \ldots \ldots \ldots$ ........... T. extensus f. longispina (Kiefer, 1931) (Mexico; U.S.A., New Jersey)

8. Dorsal seta of caudal ramus inserted at a level about halfway between level of insertion of lateral caudal seta and distal end of ramus; leg 4 coupler naked or with short sparse hairs on margin $\ldots \ldots \ldots \ldots \ldots \ldots \ldots \ldots \ldots \ldots . \ldots \ldots$

- Dorsal seta of caudal ramus inserted at level of, or only slightly distal to insertion of lateral caudal seta; leg 4 coupler with long hairs on margin ....... T. schubarti Kiefer, 1935 (Brazil)

9. Caudal ramus 1.2-1.5 times longer than broad; leg 4 coupler

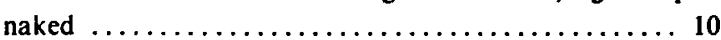

- Caudal ramus 1.7-3 times longer than broad; leg 4 coupler either naked, or (in most cases) with short sparse marginal 
hairs ........T. prasinus species-complex (Table V)

10. Caudal ramus 1.5 times longer than broad; inner terminal spine of leg 4 endopodite 3 about 2 times length of endopodite 3 ........... T. schubarti dispar Herbst, 1962 (Brazil)

- Caudal ramus 1.2 times longer than broad; inner terminal spine of leg 4 endopodite 32.4 times length of endopodite 3 ................ T. piscinalis Dussart, 1984 (Brazil)

\section{Acknowledgments}

I thank Mestre Bárbara Robertson of the Instituto Nacional de Pesquisas da Amazônia (INPA) for the gift of the specimens from Balbina, which were collected by Mestre Ednaldo Nelson dos Santos Silva with the support of the Eletronorte Power Company. The Departamentos de Biologia Animal and Biologia Vegetal provided laboratory and field facilities during my several years' stay at the Universidade de Brasilia; special thanks are due to colleagues who assisted with collecting during that period: Drs. Anthony B. Bosworth, Alan E. Mill, and Isa G. TorresPereira, and Mestre Lourdes Elmoor-Loureiro. The preparation of this article was supported by a Smithsonian Senior Postdoctoral Fellowship.

\section{References}

Dumont, H.J.F., 1981. Cladocera and free-living Copepoda from the Fouta Djalon and adjacent mountain areas in West Africa. Hydrobiologia, 85: 97-116.

Dussart, B.H., 1983. Copépodes des Antilles françaises. Rev. Hydrobiol. trop., 15 (4) 1982: 313-324.

Dussart, B.H., 1984. Copépodes d'eau douce de Guyane française. Rev. Hydrobiol. trop., 16 (4) 1983: 321-325.

Dussart, B.H. \& C.H. Fernando, 1986. Remarks on two species of copepods in Costa Rica, including a description of a new species of Tropocyclops. Crustaceana, 50 (1): 39-44.

Gurney, R., 1933. British fresh-water Copepoda, III: 1-384
(The Ray Society, London).

Herbst, H.V., 1959. Brasilianische Süsswassercyclopoiden (Crustacea Copepoda). Gewäss. Abwäss., 24: 49-73.

Kiefer, F., 1931. Die Untergattung Tropocyclops der Gattung Eucyclops (Copepoda Cyclopoida). Z. wiss. Zool., 138: 487-514.

Kiefer, F., 1935. Ueber drei Cyclopiden (Crustacea Copepoda) aus Brasilien. Zool. Anz., 112: 23-31.

Kiefer, F., 1938. Ruderfusskrebse (Crust. Cop.) aus Mexico. Zool. Anz., 123: 277-280.

Kiefer, F., 1956. Freilebende Ruderfusskrebse (Crustacea Copepoda) I. Calanoida und Cyclopoida. Ergebn. dt. Limnol. Venezuela-Exped., 1: 233-268.

Lindberg, K., 1955a. Cyclopides (Crustacés Copépodes) de l'Amérique du Sud. Ark. Zool., (2) 7 (11): 193-222.

Lindberg, K., 1955b. Cyclopoïdes (Crustacés Copépodes) du Mexique. Ark. Zool., (2) 7 (23): 459-489.

Lindberg, K., 1955c. Cyclopides (Crustacés Copépodes) récoltés au Pérou par le Dr Hernando de Macedo. Folia biol. Andina, 2 (Zool., 1): 1-18.

Pennak, R.W., 1989. Fresh-water invertebrates of the United States (3rd ed.): 1-628 (Wiley, New York).

Reid, J.W., 1985. Chave de identificação e lista de referências bibliográficas para as espécies continentais sulamericanas de vida livre da ordem Cyclopoida (Crustacea, Copepoda). Bolm. Zool. Univ. São Paulo, 9: 17-143.

Riera, T., 1981. Expressio geografica de la variabilitat d'un Copépode cosmopolita d'aigua dolca. Treb. Inst. Catalana Hist. nat. Barcelona, 9: 163-168.

Riera, T. \& M. Estrada, 1985. Dimensions and allometry in Tropocyclops prasinus. Empirical relationships with environmental temperature. Verh. int. Verein. Limnol., 22: 31593163.

Torke, B.G., 1976. A key to the identification of the cyclopoid copepods of Wisconsin, with notes on their distribution and ecology. Wisconsin Dep. nat. Resources, Madison, Res. Rep., 88: 1-15.

Yeatman, H.C., 1959. Cyclopoida. In: W.T. Edmondson (ed.), Ward \& Whipple's fresh-water biology: 795-815 (Wiley, New York).

Received: 17 October 1989 